\title{
Social Capital and Its Transformations in Sidogiri Islamic Boarding School
}

\author{
Farahdilla Kutsiyah \\ Institut Agama Islam Negeri Madura \\ email: keindahanmaduraku@gmail.com
}

\begin{abstract}
Treasures about Islam in Indonesia cannot be separated from pesantren (Islamic boarding school). The contribution to the development of social and cultural, especially through the preservation of local culture. This paper discusses social capital and its transformations in Pondok Pesantren Sidogiri, Pasuruan Regency. This study applied ethnography method. The research findings show internalized social capital includes social interaction ties such as routine recitations, alumni bonds, and togetherness inthe style of pondok pesantren, istighozah, haul, akhir sanah and cooperation with other institutions outside pesantren. Norms consist of love and obedience to masyaikh also his family, santri Sidogiri are one brotherhood, discipline, barokah (divine blessing), and independence in the economy, as well as honest and trustworthy behavior. Shared vision contain the development of science and institutions for the affirmation of ahlus Sunnah wa jamaah, khidmah lil ma'had khidmah lil ummah, ibadillah sholihin, simplicity, and creating entrepreneurship. Meanwhile, the transformation of social capital are the expansion of the pesantren network through the development of the organizational structure - establishment of new institutions and
\end{abstract}


institutionalize of khidmah lil ma'had and khidmah lil ummah. The social capital has a big enough impact, not only to create santri who own a strong religious knowledge and entrepreneurial spirit but also as a major trigger in the success of Pondok Pesantren Sidogiri in developing its economic business. The productive culture attached to social capital, moreover the increasing stock of social capital intend to combines two aspects namely clinging ahlusunnah wal jamaah and responding to advancement of science and technology.

[Artikel ini membahas modal sosial dan transformasinya di Pondok Pesantren Sidogiri (PPS), Kabupaten Pasuruan. Oleh karena itu, penelitian ini menggunakan metode etnografi. Temuan penelitian menunjukkan. Modal sosial yang terinternalisasi dalam keluarga besar dari Pondok Pesantren Sidogiri mencakup ikatan interaksi sosial seperti pengajian rutin, ikatan alumni, dan kebersamaan ala pondok pesantren, istighozah, haul, akhir sanah dan kerjasama dengan lembaga di luar Pesantren. Norma terdiri dari cinta dan kepatuhan kepada Masyaikh serta keluarganya, santri sidogiri merupakan satu saudara, disiplin, barokah, dan kemandirian dalam ekonomi, serta perilaku jujur dan dapat dipercaya. Visi bersama berisi pengembangan ilmu dan lembaga untuk penegasan ahlus Sunnah wa jamaah, khidmah lil ma'had khidmah lil ummah, ibadillah sholihin, kesederhanaan, dan mencetak lahirnya banyak wirausaha. Transformasi modal sosial dalam PPS yakni perluasan jaringan pesantren melalui pengembangan struktur organisasi - pembentukan institusi baru dan pelembagaan khidmah lil ma'had dan khidmah lil ummah. Modal sosial tersebut memiliki dampak yang cukup besar tidaha hanya untuk mencetak santri yang memiliki ilmu agama kuat dan jiwa wirausaha tetapi juga sebagai pemicu utama keberhasilan PPS dalam mengembangkan ekonomi bisnis. Budaya produktif melekat pada modal sosial, bahkan peningkatan persediaan modal sosial mengarah pada penggabungan dua aspek yaitu menanamkan ahlusunnah wal jamaah dan merespons kemajuan ilmu pengetahuan dan teknologi.]

Keywords: social capital; Islamic boarding school; transformation

\section{Introduction}

Since its birth, Islam has the main characteristics and strength of carrying out theological and social transformation both at the center of its birth in Mecca and outside of Saudi Arabia when Islam spread to 
various nations. For this reason, for fourteen centuries, in every place Islam has built its own civilization because of the complete conception of its teachings. ${ }^{1}$ Islamic civilization and culture are built on a combination of values of devotion, equality and creativity from within Islam that are universal with reciprocal acculturation of local cultures. ${ }^{2}$

When Islam came to the Nusantara (Indonesia archipelago), it caused the creation of various forms of change or transformation patterns with different cultural products. Islam has come to Indonesia it's cannot be separated from the nuances where Islam was born. However, Islam entered the Nusantara ability to adapt to local culture. The process of Islamic compounding with Nusantara culture so that Islam was accepted by society. ${ }^{3}$

Islamic boarding schools (pesantren) is an Islamic group entity which contributes that significantly to the dynamics of the development of Islam in Indonesia. ${ }^{4}$ Treasures about Islam in Indonesia cannot be separated from Pesantren. The contribution to the development of social and cultural life of the community, especially through the preservation of local culture in pesantren. Therefore it is not surprising that some people describe pesantren as the real face of Islam in Indonesia. It means, pesantren are not only identical with Islamic meanings, but also Indonesian's. In other words, pesantren develop from the sociological experience of the community environment and also have close connection that are inseparable from the surrounding community.

Based on the combination of Islamic teachings (Ahlusunnah wal jamaah) and local traditions and through a series of time to time from generation to generation the characteristics of pesantren are always tied to Islamic values and indigenous styles. It is also

1 Moeflich Hasbullah, Islam dan Transformasi Masyarakat Nusantara kajian sosiologi sejarah Indonesia (Jakarta: Kencana, 2017), 40.

${ }^{2}$ Asnawan, "Islam dan Akulturasi budaya lokal di Indonesia," Jurnal Falasifa 2, no. 2 (2011):90.

3 M. AT Arsyad, "Kajian Kritis Tentang Akulturasi Islam dan Budaya Lokal," Lentera Pendidikan 15, no. 2 (2012): 211.

4 A. Maulani, "Pembaruan Dan Peran Sosial Transformatif Pesantren Dan Islam Indonesia," Sosiologi Reflektif 10, no. 2 (2016): 159. 
considered as a sub culture unique, which is internalized characteristics: (1) the most important position in its value is the achievement of acceptance at Allah's side. ${ }^{5}$ (2) a strong orientation towards the kyai (a leader of pesantren), namely the asymmetrical traditional authority relationship between kyai and santri (someone who participates in Islamic education at a pesantren). Kyai and their assistants (ustad) are the only one power hierarchy that is explicitly recognized in pesantren and community around the pesantren location. In the tradition, teachers are considered as distributors of barokah (divine blessing) and reflected adherence to kyai is based on the kyai's purity, because he holds the key to channel knowledge from God. ${ }^{6}$ (3) personal character such as independence, simplicity and solidarity. ${ }^{7}$ (4) pesantren networking is quite solid. ${ }^{8}(5)$ high solidarity among santri. ${ }^{9}$ (6) the environmental community generally exists in rural areas with the farmers and traders' followers. ${ }^{10}(7)$ high tolerance to Indonesian culture. ${ }^{11}$

These characteristics are social capital owned by the pesantren. Referring to Putnam, social capital is a term developed primarily by sociologists to describe "feature of social organization such as networks, norms, and social trust that facilitate coordination and

5 Abdurrahman Wahid, "Pesantren sebagai Subkultur," Pesantren dan Pembaharuan, ed. M. Dawam Rahardjo (Jakarta: Cetakan Keempat, Lembaga Penelitian, Pendidikan dan Penerangan Ekonomi dan Sosial, 1988), 42.

${ }^{6}$ Zamakhsyari Dhofier, Tradisi Pesantren: Studi tentang Pandangan Hidup Kyai (Jakarta: Lembaga Penelitian, Pendidikan dan Penerangan Ekonomi dan Sosial (LP3ES), 1983), 82.

7 M.M. Billah, "Pikiran Awal Pengembangan Pesantren," Pergulatan Dunia Pesantren Membangun dari Bawah, ed. M. Dawam Rahardjo (Jakarta: Cetakan Pertama, Perhimpunan Pengembangan Pesantren dan Masyarakat (P3M), 1985), 291.

8 Hamdan Farchan dan Syarifudin, Titik Tengkar Pesantren: Resolusi Konflik Masyarakat Pesantren (Yogyakarta: Pilar Religia, Kelompok Pilar Media, 2005), 67.

${ }^{9}$ Abdurrahman Wahid, "Pesantren sebagai Subkultur, 45.

${ }^{10}$ M. Dawam Rahardjo, "Dunia Pesantren dalam Peta Pembaharuan," Pesantren dan Pembaharuan, ed. M. Dawam Raharjo (Jakarta: Cetakan Keempat, Lembaga Penelitian, Pendidikan dan Penerangan Ekonomi dan Sosial, 1988), 1-6.

11 Maulani, Pembaruan Dan Peran Sosial Transformatif Pesantren Dan Islam Indonesia, 161. 
cooperation for mutual benefits". ${ }^{12}$ Social capital is also defined as the information, trust, and norms of reciprocity inhering in one's social networks-seemingly obvious opportunies for mutually beneficial collective action are squandered. ${ }^{13}$ The World Bank, which previously followed and promoted a markedly neo-liberal approach, now acknowledge social capital as a useful tool for poverty reduction, ${ }^{14}$ so that the World Bank adopted and encouraged the idea of social capital as a "missing link" in explaining development or its absence, not least because of its view of social capital as "the glue that holds society together". ${ }^{15}$ Ceteris paribus, one would expect communities blessed with high stocks of social capital to be safer, cleaner, wealthier, more literate, better governed and generally "happier" than those with low stocks, because their members are able to find and keep a good jobs, initiate projects serving public interests, costless monitor one another's behavior, enforce contractual agreements, use existing resources more efficiently, resolve dispute resolution more amicably, and response to citizens concern more promptly. ${ }^{16}$

Social capital in Indonesia is influenced by religious values such as pesantren is seen as more important and integrated on a broader scale towards various aspects of the lives of Indonesian people. ${ }^{17}$ As explained in the previous section, pesantren have high stocks of social capital, when it can be managed properly it will become a great power as well as being able to become the center of Islamic civilization in Indonesia.

\footnotetext{
${ }^{12}$ Dell Chaplin, "Social Capital and the Privatization of Public Goods, " International Journal of Social Economics, MCB University Press 26 no.10/11 (1999): 1.304.

${ }^{13}$ Michael Woolcock, "Social Capital and Economic Development: Toward a Theoretical Synthesis and Policy Framework." Theory and Society. 27. Printed In The Netherlands: Kluver Academic Publisher, (1998): 153.

${ }^{14}$ Joe Wallis, Paul Killerby, and Brian Dollery, Social Economics and Social Capital, International Journal of Social Economics 31, no. 3 (2004):239.

${ }^{15}$ Ben Fine and Costas Lapavitsas, "Social Capital and Capitalist Economies," Asecu South Eastern Europe Journal of Economics 1 (2004): 21.

${ }^{16}$ Michael Woolcock, Social Capital and Economic Development, 155.

17 R. Permani, The economic of Islamic Education: Evidence from Indonesia (University of Adelaide, Thesis 2009).
} 
According to Muhammad Fethullah Gulen, every civilization must have a relationship with its past, and have a relationship with its cultural heritage. Therefore, searching and developing a better civilization for the future will not succeed except by taking that they have. ${ }^{18}$ Pesantren must be equipped with the highest ability to respond to the challenges and demands of life in the context of space and time that exist in Indonesia and the world of the present century. ${ }^{19}$ To achieve these noble ideals, of course there must be a reinterpretation of the values and traditions that they have so that pesantren are able to carry out social transformation. Pesantren is not only to maintain its existence, but more than that, by adjustments, accommodation and concessions can develop and even be able to settle themselves in an important position as the center of Islamic civilization in Indonesia. Which in turn, the authenticity of the pesantren as the embodiment of the face of Indonesian Islam become rahmatan lil'alamin for various groups, class differences as well as existing cultural diversity. ${ }^{20}$

The Sidogiri Islamic Boarding School (Pondok Pesantren Sidogiri $=$ "PPS") was established in 1718/1745. PPS is one of the oldest Islamic boarding schools, ${ }^{21}$ and the best in Indonesia. ${ }^{22}$ PPS is an example of success in sharia economic development, which continues to spread its wings to various regions throughout Indonesia. In terms of innovation, the PPS solves social problems in innovative ways that integrate local wisdom and social entrepreneurship in the form of Kopontren Sidogiri, Agro Cooperative, Sidogiri Library and

\footnotetext{
${ }^{18}$ Usman Syihab, "Peranan Agama dalam Restorasi Peradaban Umat Islam Menurut Muhammad Fethullah Gulen," Jurnal Tsaqafah 10, no. 2 (2014):

19 Nurcholish Madjid, Merumuskan Kembali Tujuan Pendidikan Pesantren, Pergulatan Dunia Pesantren Membangun dari Bawah (Jakarta: Cetakan Pertama, Perhimpunan Pengembangan Pesantren dan Masyarakat (P3M), 1985), 3-15.

20 Maulani, Pembaruan Dan Peran Sosial Transformatif Pesantren Dan Islam Indonesia.

21 Dzikra Majalah Ijtihad, Jejak langkah 9 Masyaikh Sidogiri 1 Edisi keempat (Pasuruan: Pustaka Sidogiri PP Sidogiri, 2013a), 7.

22 Dewi Masyitha \& Alvan Fathony, "Studi Analisis Peran Pesantren Sidogiri Dalam Pembentukan Karakter Kemandirian Ekonomi Masyarakat Perspektif Sosiologi," Profit 01 no 01, (2017).
} 
Sidogiri Bulletin. ${ }^{23}$ In this context, social capital and its transformation in PPS are interesting to observe.

One of the strategies that could be done in order to optimize the rural development is by involving pesantren (Islamic boarding schools) as social capital. As we all know the population of pesantren in East Java is the largest and is spread almost in all villages in the province of East Java. ${ }^{24}$ Local community benefits from more intense interaction with the local religious leaders of Pesantren than does the external community. ${ }^{25}$ Pesantren contribute to the formation of social capital, particularly in the form of religiosity, which contribute to the improved welfare of the surrounding community. ${ }^{26}$

The impact of social and cultural capital on the development of character education is the strengthening of the client-patron culture between kyai or ustad and santri. ${ }^{27}$ A blessed value system (barokah), obedience, honesty, and solid network between peasants and pesantren are internalized in pesantren environtment. This capital has been rooted in peasant life and influenced the implementation of pesantren economic activity. ${ }^{28}$ The transaction cost of peasants in collaboration among pesantren business and them in block grant program depend on institutional operational each pesantren. This condition was caused by

\footnotetext{
${ }^{23}$ Azel Raoul Reginald dan Imron Mawardi, "Kewirausahaan Sosial Pada Pondok Pesantren Sidogiri Pasuruan," JESTT 1, no. 5 (2014).

24 Salis Ulinuha Ahmad, "Pesantren Sebagai Modal Sosial Dalam Strategi Pembangunan Desa di Jawa Timur," Akademika 7, No. 1 (2013): 79.

${ }^{25}$ R. Permani, "The presence of religious organisations, religious attendance and earnings: Evidence from Indonesia," The Journal of Socio-Economics 40 (2011): 247.

${ }^{26}$ Ibid

${ }^{27}$ Sopidi, "Integrasi Modal Sosial Dan Budaya Dalam Pengembangan Nilai-Nilai Pendidikan Karakter Di Pondok Pesantren Modern As-Sakinah Sliyeg Indramayu," Holistik 15, no. 02, (2014): 287.

${ }^{28}$ Farahdilla Kutsiyah, Analisis Modal Sosial dan Biaya Transaksi Pengembangan Agribisnis di Pesantren (kasus: program bantuan pinjaman langsung masyarakat pada dua pesantren di Kabupaten Pamekasan), Malang: Disertasi Universitas Brawijaya, (2008):iv.
} 
the differences of governance structure, behavioral attributes of peasant or chairman of a group, pesantren networks and uncertainty. ${ }^{29}$

The strategy of PPS in realizing civil society is to build networks, both internally and with the personal or external institutions. Then they build relationships with the banking, government, social groups, and so on. In addition, it fosters trust in Sidogiri's internal for creating together meaning. The pattern of relations between cooperatives, BMTs with customers or financiers is a manifestation of trust to get profit together. ${ }^{30}$

Dimensions of religion, culture, tradition and institutional approach affect entrepreneurial activity. The proses implementation of entrepreneurship education in PPS integrating with religious subjects especially, in fiqh al-mu'amalat, and extracurricular form senior students and alumni of pesantren through strategy - santri are trained to manage the existing economic institutions in boarding schools under the supervision and guidance of kyai, ustad (teacher), administrators, senior santri and alumni through spiritual values plus entrepreneurship that is internalized in PPS is religious and entrepreneurial values based on Ibadah (worship to God) and Khidmah (services for mankind), where all business and economic activities undertaken intended to worship Allah SWT; reverence to the community. ${ }^{31}$

\section{Methods}

This study aims to describe social capital and its transformations at Pondok Pesantren Sidogiri (Sidogiri Islamic boarding school) in Pasuruan Regency. Therefore, this study applied

\footnotetext{
29 Farahdilla Kutsiyah, "Analisis Kinerja Program bantuan Pinjaman langsung Masyarakat Melalui Lembaga pesantren di Madura." Jurnal Agro Ekonomi (JAE), Pusat Analisis Sosial Ekonomi Dan Kebijakan Pertanian, Puslitbang Bogor (2009): 109.

${ }^{30}$ Muhammad Sulton Fatoni, Strategi organisasi Pondok Pesantren Sidogiri dalam mewujudkan civil society: Analisa kapital social, UI: Tesis (2006).

31 Abdulloh Kasor, Eri Pratikto, Agung Winarno, "Spiritual Entrepreneurship Education in Islamic Boarding School: A Case Study at Pondok Pesantren Sidogiri Pasuruan, Each Jawa, Indonesia," International Journal of Academic Research in Business and Social Sciences 7, no. 6 (2017): 392.
} 
ethnography method to interpret the phenomenon in PPS environment. Referring to Malinowski, the main purpose of ethnographic research is "to grasp the native point of view, its relation to life, to realize its vision and its world". ${ }^{32}$ The respondent are santri, ustad, administrators, alumni and the community in the Islamic boarding school as well as supported by documentation and literature review to make accurate and objective findings.

The social capital literature focuses on three dimensions: structural, relational, and cognitive. ${ }^{33}$ The structural dimension refers to the overall patterns of relationships among individuals, such as social interaction ties, ${ }^{34}$ while the relational dimension pays attention to personal relationships that people have mutually developed over a history of interactions. The cognitive dimension is regarded as those resources enabling shared representations, interpretations, and systems of meaning among the parties involved, and the key facets of this may be a shared language, culture, and vision. ${ }^{35}$ The scope of social capital in this article includes three dimensions such as social interaction ties (structural dimension), norm reciprocity (relational dimension) and shared vision (cognitive dimension) that are internalized in the environment of the Sidogiri family.

\section{Results}

\section{Social Capital Stock in Sidogiri Islamic Boarding School Environment}

The journey of PPS has approached 300 years, still the same as its inception, upholding the principle of salaf in the style of ahlus sunnah wa jamaah. In other words, the adopted system is the

\footnotetext{
32 James P. Spradley, Metode etnografi. Penerjemah M.Z. Elizabeth. (Yogya: PT Tiara Wacana, 1997).

${ }^{33}$ J. Nahapiet, S. Ghostal, "Social capital, intelectural capital, and the organizational advantage." Acad manage Rev. 23. (1998).

${ }^{34}$ Y Lu, D.Yang, "Information Exchange In Virtual Communities Under Extreme Disastercondition,” Desic Support Syst 50 (2011).

${ }^{35}$ H.H. Chang, C. Y. Hung, C.Y. Huang, K.H. Wong and Y. Tsai, "Social capital and transaction cost on co-creating IT value towards inter-organizational EMR exchange.” International Journal of Medical Informatics (2011).
} 
education of Pesantren with "kitab kuning" as the basis. As an explanation, Kitab kuning is a traditional book containing the teachings of Arabic or Arabic font written by Muslim intellectuals of the past (salaf) popularly known as imam, kyai or masyaikh. Coverage of Kitab kuning start from jurisprudence (Islamic laws), aqeedah, morals (ethics), sufism, Arabic grammar (nahwu sharaf), hadiths, interpretations, hadith Sciences to medicine or medical (thibb) ${ }^{36} \mathrm{Sa}$ 'di abu Jaib said, etymologically ahlus sunnah wa jamaah is formed from three words: Ahlu, as-Sunnah, and al-jama'ah. Ahlu has the meaning of family, followers and class. As-sunnah means the meaning of tariqah (path and behavior), whether the path is right or wrong, fulfilled or not. ${ }^{37}$ The meaning of sunnah in terms of terminology has the meaning of the way taken by the Messenger of Allah and his companions who survived error and lust. ${ }^{38}$ While the third word, aljama'ah means people who maintain togetherness and collectivity in achieving a goal. Ibn Taimiyah interpreted ahlus sunnah wa jamaah as the majority group of muslims. According to him, those who speak based on the Qur'an, sunnah and ijmak, then they belongs to the group ahlus sunnah wal jamaah. ${ }^{39}$

The ahlus sunnah wa jamaah trilogy covers aspects of belief (aqidah), Islamic law (sharia) and tasawuf (moral). The three of them are one teaching unit that covers all aspects of Islamic religious principles based on the Ash'ari-Maturidi manhaj (thought) as the formulator of Akidah. ${ }^{40}$ Four schools of thought (Mahzab/paths or streams) in the field of jurisprudence namely the Hanafi, Maliki, Syafi'i and Hambali schools. Jurisprudence is interpreted as a characteristic possessed by mujtahid, in the form of legal products

\footnotetext{
${ }^{36}$ M. Masyhuri Mochtar, Dinamika kajian Kitab kuning Di Pesantren (Pasuruan: Pustaka Sidogiri. PP Sidogiri, 2016), 20.

37 Batartama Pondok Pesantren Sidogiri (PPS), Trilogi Ahlusunah: Akidah, Syariah dan Tasawuf, 15.

${ }^{38}$ Al-Hambali in Batartama Pondok Pesantren Sidogiri, 15.

39 Taimiyah in Batartama Pondok Pesantren Sidogiri, 31-32.

${ }^{40}$ PWNU, Jawa Timur, Aswaja An-Nahdliyah, Ajaran Ahlussunnah wa Al-jamaah yang Berlaku di Lingkungan Nahdlatul Ulama (Khalista Surabaya dan LTN NU Jawa Timur, 2007), 3.
} 
furu'iyah which are ijtihadi and extracted from the zhanni (assumption) arguments. In the field of Sufism adheres to Manhaj Ali Zainal Abidin, Abu Yazid Al Bistami, Al-Harith al-Muhasibi, Junaid al-Baghdadi, Imam al-Ghazali and other imams who are in line with Islamic law. ${ }^{41}$

The main values of Sufism are sincerity, zuhud (life is only for Allah swt), holding back lust, Istikamah in worship. The main points of Sufism teachings are the silence of the heart and muhasabah (selfcorrecting), the goal is only Allah, live zuhud and always feel need for God, strengthen the heart of mercy and love, and lastly adorn themselves with alkhlaqul karimah. ${ }^{42}$

As the number of santri grows, then the pesantren develop into a religious community, in a certain pattern of life in which learning and religious practices become the main concentration. ${ }^{43}$ This means that kyai and pesantren are the basis of the formation of the santri which are derived from the character of the teaching model in the pesantren which was built and developed by the kyai. The teaching model, mastery of Islamic knowledge and the authority of kyai in their pesantren are social and intellectual capital of kyai in translating Islam and forming Islamic traditions at Islamic boarding schools and their environmental communities. ${ }^{44}$

The teaching model character of PPS, the Islamic understanding and scientific knowledge of the masyaikh with a touch of local culture eventually became the forerunner of the social capital of the santri and alumni as well as the santri guardians and communities where PPS were located. In the long run from generation to generation has become the social capital of the santri family. Embedded social capital in the family environment of PPS represented in Figure 2. The scope of social capital includes social interaction ties (structural dimension), norm reciprocity (relational dimension) and

\footnotetext{
${ }^{41}$ Batartama Pondok Pesantren Sidogiri (PPS), Trilogi Ahlusunah, 276-280.

42 Ibid. 280-310.

${ }^{43}$ Hasbullah, Islam dan Transformasi Masyarakat Nusantara, 90.

${ }^{44}$ Ibid, 109.
} 
shared vision (cognitive dimension) that are internalized in the environment of the Sidogiri family.

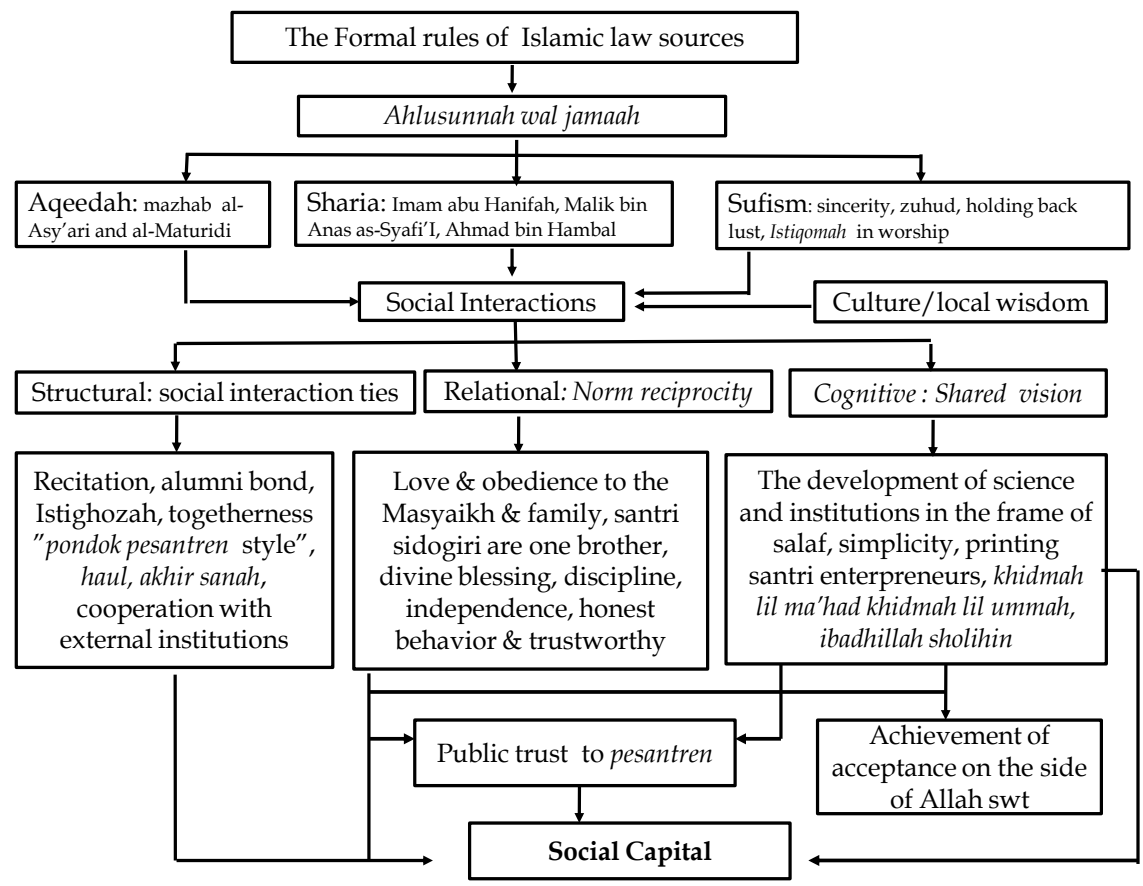

Figure 2. Internalized social capital in "a big families" of the Sidogiri Islamic Boarding School

\section{Structural: Islamic Boarding School Network}

Structural dimensions refer to the overall pattern of relations among individuals, such as social interaction ties (network) of PPS consist of routine recitations, alumni ties, togetherness in the style of pondok pesantren, istighozah, haul and akhir sanah and cooperation with other institutions outside pesantren.

The recitation is carried out routinely both with alumni and the community in each region spread across Indonesia. Every month the event is held which is attended by the family of masyaikh. For 
example, currently the recitation of alumni in Pasuruan Regency is divided into two regions namely the western and the eastern region. The event is usually held on sweet Friday (alike sacred Friday). The number of congregations present was around 500 people in each region. This routine activity aims to strengthen faith because human faith is often up and down. As well as to further strengthen relations with the pesantren through turned on again the pesantren activity. In the previous section has been explained that Sidogiri is one of the oldest Pesantren, so it is nor suprising at this event the alumni were present from various professions ranging from traders, farmers, government officers till famous kyai who already had pesantren with more than one thousands of santri.

There is local wisdom that is implemented istiqomah (continually), in most of the pesantren there is a tradition, santri visit kyai, but in Sidogiri kyai comes every month to visit in each region to meet alumni and society in the form of recitation. This condition encouraged alumni and the community to attend the recitation on the sidelines of their daily activities.

Status of santri is for life. Graduation from pesantren always be santri or the term they are santri alumni. The ideals of their struggle never change, it is still the same, continuing the struggle to give a better for society. Even though the alumni have left the Pesantren, they are still imprinted in their desire to serve the Pesantren and the community. Some of the alumni won the trust of the kyai by being chosen as administrators who facilitated pesantren activities as well as cooperating with external institutions outside the PPS. Some of them become employees. The alumni association will work hand in hand when one of their siblings experiences difficulties and will share when success is achieved by another brother. We could see this picture in a variety of alumni activities both at the central and branch level (region).

In education and da'wah sector, through recitation in each branch, sending assignment teachers, branch schools, Darul Aitam (madrasah for orphan), scholarships from zakat institutions and waqf sidogiri institutions etc. In the economic sector, incorporated in the 
economic activities of pesantren, such as pesantren cooperatives and businesses among alumni such as BMT Sidogiri. Reginald et al (2014) Now Sidogiri has a series of businesses including (1) Pesantren cooperatives, (2) BMT Maslahah (3), BMT Integrated Joint Venture UGT (4) Ummu Syariah BPR (Financial services), (5) Agro cooperatives (6) SBC Sidogiri (Islamic Financial Services Professional Training) (7) LAZ Sidogiri (Amil Zakat Institution) (8) L-KAF Sidogiri (Waqf Institution) (9) Sidogiri Bulletin magazine, and (10) Publishing Sidogiri Library. The alumni and santri as managers, owners and employees.

Togetherness of pondok pesantren-style can be illustrated as follows: the choice to become a santri means that they is willing to leave home and away from both they parents and families. Daily habits at home cannot be done anymore. He must follow the rhythm outlined in the pesantren's order. The daily life that they do surely is praying together, eating together, sleeping together and studying together with their fellow santri. This is the beginning of the network formed and solidarity binding between them. The feeling of one fate, one struggle and one dream made their bond strong even they have graduated from a pesantren.

Haul, akhir al-sanah, and Istighozah are regular meetings held by santri, alumni, sometimes guardians of santri and the community. For example, haul of deceased KH. Nawawi. They are present at their own initiative and desire. The big names of the kyai Nawawi are inherent in the hearts of the people. ${ }^{45}$ This fact can be seen when the haul and akhir sanah, including santri, alumni, the community, and even the government will participate and take the time, energy and costs for the success of the event. This routine activities are not only a religious nuance, but also an infrastructure for santri, alumni, communities, religious leaders, and stakeholders to communicate and interact directly about everything (political, economic, social, etc.) according to capacity and needs each of them.

45 Chusnul Chotimah, "Strategi Public Relations Pesantren Sidogiri Dalam Membangun Citra Lembaga Pendidikan Islam," Islamica 7, no. 1, (2012): 201-202. 
PPS collaborates with various external institutions. In education sector to deal with the issue of the legality of certification of its graduates, PPS relates to the government. The economic sector cooperate with Islamic Banking Partners so that the financial capital stock to help small communities can be expanded. To increase human resources, PPS collaborates with various universities, especially the collaboration that has been established for a long time with TAZKIA Institute, Bogor. Community economic empowerment is done through Santri Alumni Association of Sidogiri (IASS), Sidogiri Islamic Boarding School Cooperative (Kopontren Sidogiri), BMT-MMU Cooperative Sidogiri, BMT UGT Sidogiri, Agro Sidogiri Cooperative, LAZ \& L-KAF Sidogiri, Sidogiri Bulletin, Sidogiri Library etc. Masyitha \& Alvan, $(2017,137)$ Sidogiri is currently famous as a pesantren that has managed to be financially independent. ${ }^{46}$ Various businesses was built by pesantren foundations such as the minimarket (Mart) franchise called Kopontren Sidogiri, a financial institution called BMT (Baitul Mal Wat Tamwil) and many other businesses.

The success of PPS in developing its economic business is supported by networking built with other business institutions, and entrepreneurial management that is variably partially integrated structural and non structural which gives greater flexibility to the business institution to develop its business. ${ }^{47}$

\section{Reciprocity Norm}

Norms internalized in the PPS family environment are love \& obedience to Masyaikh \& the family, santri sidogiri is one brother, discipline, barokah, and independence in the economy, as well as honest \& trustworthy behavior. The characteristic of Sidogiri hold the salaf culture firmly such as respect to kyai, the spirit of serving Pesantren and the community, obtaining blessing, humble, zuhud

\footnotetext{
${ }^{46}$ Dewi Masyitha \& Alvan Fathony, "Studi Analisis Peran Pesantren Sidogiri Dalam Pembentukan Karakter Kemandirian Ekonomi Masyarakat Perspektif Sosiologi," Profit 01, no 01 (2017): 137.

47 Salis Ulinuha Ahmad, "Pesantren Sebagai Modal Sosial Dalam Strategi Pembangunan Desa di Jawa Timur," Akademika 7, no. 1 (2013): 7.
} 
solely to gain knowledge and sincerity. Because of this reason, santri will have the nature of obedience, tawadhu 'and respect for his teacher.

The figure of a Kyai or often called the charismatic influence of masyaikh, because of the actions of the Kyai who always leads to goodness. Masyaikh or Kyai Sidogiri have full knowledge and experience of Jurisprudence and Sufism. Besides that, he has special characteristics, namely istikamah in worship and khumul or low profile, whose is not self-centered. ${ }^{48}$ It is imprinted that Barokah will continue to flow and has a tremendous influence on the success of the alumni because the prayer of a masyaikh. An honor and excellence for santri and alumni when given the trust from kyai. One of Kopontren Sidogiri's administrator said: "We work told by the Kyai to be pleased masya Allah. An honor and privilege for santri ... it's because of love."

Barokah means ziyadatul khair, namely "increasing goodness". Al-Qawlal-Badi fial-Shalah ala al-Habib al-Syafi'I interpreting barokah as developing and increasing goodness and glory. ${ }^{49}$ It is an increase in the quality and quantity of Gods blessings via unseen ways to human life. ${ }^{50}$ Barokah is usually associated with karomah. Karomah is a trait attached to a saint who is able to transfer God's help to those who need it. Because of his karomah, saints can do extraordinary things. ${ }^{51}$ In the tradition of pesantren, the teacher is considered to be a barokah distributor and reflected obediance with a teacher is based on the belief that the teacher has holiness, because it holds the key to channeling knowledge from Allah. ${ }^{52}$

Santri sidogiri is one brother "santriku kabeh sa'duluran" or which is known as the general term ukhuwah islamiyah, is a deceased

\footnotetext{
${ }^{48}$ Dzikra majalah. Jejak langkah 9 Masyaikh Sidogiri, (2013b), 8.

49 Muhyiddin Abdusshomad, Fiqh Tradisionalis Jawaban Berbagai Persoalan Keagamaan Sehari-Hari (Malang: Pustaka Bayan bekerja sama dengan PP Nurul Islam, 2004), 91.

${ }^{50}$ Serdar Demirel and Hikmatullah Babu Sahib, “Concept of Barakah in Qur'ān and Sunnah: Towards its Realization in Modern Discourse" FSM İlmî Araştırmalar Insan ve Toplum Bilimleri Dergisi, 5 (2015): 261.

51 Endang Turmudi, Perselingkuhan Kiai dan Kekuasaan (Supriyanto Abdi (Penerjemah) Yogyakarta: LKiS, 2004).

${ }^{52}$ Zamakhsyari Dhofier, Tradisi Pesantren: Studi tentang Pandangan Hidup Kyai.
} 
tausyiah masyaikh Cholil Nawawi. This taushiyah is truly embedded in the students and alumni. The message gave emotional strength so that the unity and brotherhood of fellow alumni became stronger. Even the alumni association exceeds than theirs families ties and has made Sidogiri grow until now.

Discipline and independence are instilled in the santri from an early age. They are not only receive education in Madrasah (academic), but also provide non-academic education (Makhadiyah). Makhadiyah activities are more complex because they are integrated with the daily activities of santri such as tahajud, witir, and dawn in congregation, dhuha prayers in congregation, midnight prayer and asar congregation and maghrib prayer congregation, where prayer has very deep educational values. In addition, other makhadiyah activities is istighozah, burdah, recitation of kitab kuning, reading the PPS law book etc. The value instilled early on is religious value, among others uswah alhasanah, discipline, independence, values of worship, morals and so on. It is expected that after graduating from pesantren, students can recognize religion perfectly and not depend on others.

Discipline is applied in the form of regulation. When they were appointed as santri, each santri received a pocket book. The contents of the book are written in order that must be obeyed by the santri and enforcement of the punishment is applied to anyone who violates it. Discipline (istiqamah) and independence have led the santri holding tight in fixing, modifying and making models for the development of santri's knowledge and skills by sticking to the teachings given by the masyaikh Sidogiri namely salaf ala ahlusunnah wa aljamaah so that they are expected to become santri ibadhillah sholihin

Superior individuals have ethics and morals in accordance with rasulullah characteristics such as siddiq, amanah, tabligh, and fathonah. Siddiq means honest, amanah means trustworthy, tabligh is usually interpreted as transparency, and fathonah is interpreted professionally. ${ }^{53}$ For example, the first intention of economic

53 NU, "Kopontren Sidogiri, Sukses dengan Meneladani Sifat Rasul," 2007. http://www.nu.or.id/post/read/9812/kopontren-sidogiri-sukses-dengan-meneladanisifat-rasul. 
institutions in PPS was to struggle and preach. In educating the entrepreneurial spirit of the santri hold on two things, namely siddiq and trust, basically those are the two largest and most important capital built in the character of santri. ${ }^{54}$ Siddiq, it can be defined as being truthful verbally and behaviorally. Truthfulness is not only that we should avoid it but we should do our duty honestly and live our lives not only for whom we are obliged for our health, wealth, knowledge and progress. The means of conveying to the creation that they have been commanded. Fathanah can be defined as wisdom, intelligent and sagacious. ${ }^{55}$

\section{Cognitive: Shared Vision}

Shared Vision of PPS such as the development of science and institutions for the affirmation of ahlus sunnah wa jamaah, khidmah lil ma'had khidmah lil ummah, ibadillah sholihin, simplicity, creating entrepreneurship.

"Sidogiri since its founding until now still remains firmly upholding the principle of salaf ala ahlus sunnah wa jamaah as outlined and fought by the Muassis and Masyaikh Sidogiri before, even in responding to and acting to every event and various problems especially religious issues, Sidogiri always returns on the teachings of the Salaf scholars which are summarized in the alKutubut Turats or kitab kuning which have become the world's reference to pesantren all this time. The principle continues to be the foundation and barometer, does not shift the slightest, even the handbook still the same. This principle has colored all of Sidogiri's activities both in organizations and other activities. This principle is also a guideline for santri and alumni, both individuals and

${ }^{54}$ Chusnul Chotimah, Pendidikan Kewirausahaan Di Pondok Pesantren Sidogiri Pasuruan," Inferensi, Jurnal Penelitian Sosial Keagamaan 8, no. 1 (2014): 131.

55 Ajijola 1999, Husayni 2005 and Yamada 2008 in Mohammad Noorizzuddin Nooh, "Entrepreneurship, Ethics and Religiosity," Journal of Business \& Economic Policy 2, no. 4 (2015): 177. 
institutions. This principle is the foundation and spirit in the application of two major functions of PPS, namely the function of tafaqquh fiddin and the function of da'wah", ${ }^{56}$

Values that have been internalized within themselves are devotion to Allah by upholding truth and honesty, upholding justice, maintaining unity, fostering brotherhood and togetherness in accordance with the values contained by Islamic teachings in the style of Ahlussunah Wal Jamaah. This is the foundation to become a spirit of togetherness among the alumni of Sidogiri in serving the pesantren and serving the community (khidmah lil ma'had khidmah lil ummah). The general meaning of santri is those who study Islam, either go to a place far or close to the intention to practice their knowledge and disseminate it. ${ }^{57}$ The late KH. Hasani Nawawie (Masyaikh Sidogiri) interpreted the santri as "based on the action review, the steps are those who hold fast to the Qur'an and follow the Sunnah of the Prophet and steadfastly establish themselves. This is the meaning of leaning on history and reality that cannot be replaced and changed forever. And Allah is the Knower of the truth of things and reality. ${ }^{58}$ The PPS mission is to create the pious servant of God (Ibadhillah sholihin). It means is not only for the world but also for the after life. The meaning of Ibadhillah sholihin is obedient, devout to Allah swt and cling to the sunnah of the Prophet, and have a responsible stance, both to themselves, family, society, religion, and nation.

Simplicity is an inherent characteristic of santri. Because they are used to being educated in simple life while in PPS. Fashion of the santri wear a white shirt, sarong and sandals. The transportation of the santri is bicycle and by foot. The consumption of santri is the daily menu provided by the pesantren where the residence is a dormitory, where one room measuring $3 \times 3$ meters contains \pm 20 people.

\footnotetext{
${ }^{56}$ Saifullah Naji said (daily administrator and general secretariat of PPS)

57 Saifuddin Zuhri. Guruku Orang-Orang Dari Pesantren. (Pustaka Sastra LKiS. Yogyakarta, 2001), 2001.

${ }^{58}$ Dzikra Majalah Ijtihad, Jejak langkah 9 Masyaikh Sidogiri 1: 244.
} 
The process of entrepreneurship education in PPS that students are trained to manage economic institutions in PPS, under the supervision of kyai and pesantren administrators. Profit are not the top priority, because the first instillation in entrepreneurial institutions of pesantren is all done for worship and solely hoping for God's blessing, so that the santri have a strong religious knowledge also has the entrepreneurial spirit. ${ }^{59}$

\section{Transformation of Social Capital in the Sidogiri Islamic Boarding School Environment}

The tagline among pesantren is "al Muhaafadhotu alal qadimi ash sholih wal akhdu bil jadidil ashlah". Preserve old traditions that are still good and take on new traditions that are better. Because of its view, the transformation always continues without endpoints in the PPS to produce ibadhillah sholihin santri as well as continuing what was outlined by the masyaikh khidmah lil ma'had khidmah lil ummah. The transformation of social capital in PPS concict of the expansion of the pesantren network through the development of the organizational structure and the establishment of new institutions, and institutionalize of khidmah lil ma'had and khidmah lil ummah

\section{Expansion of Pesantren Network through Development of Organizational Structure and Establishment of New Institutions}

The strength of the sidogiri is different than others pesantren cause PPS unitewhich are coupled between the karomah of masyaikh, the collective leadership (family assembly) and a good implementing of organizational structure. This organizational structure affects the performance and behavior of the organization so that these conditions create disciplined, orderly and systematic management. As explained in the previous section, the network in Sidogiri includes routine recitation, alumni ties, togetherness in the style of pondok pesantren, haul, akhir sanah, istighozah and collaboration with external

\footnotetext{
59 Chusnul Chotimah, Pendidikan Kewirausahaan Di Pondok Pesantren Sidogiri Pasuruan, 133.
} 
institutions. This network has become more massive, more coordinated and more efficient in achieving goals

The chart of the management structure of the PPS is systematic and the tasks division are clear. Each administrator has responsibility, authority and position of coordination as well as control and supervision. When there is a new branch or expansion of the main tasks and functions, an additional coordinator is made in the management structure. For example, when there is a publishing activity that can add assets to Sidogiri, the general treasurer coordinator appointed a head of the publisher, when the potential of alumni and their's utilization are so widely formed a special institution which is in a special coordination namely Santri Sidogiri Alumni Association (IASS) etc.

Masyaikh are the highest leaders who hold full authority in PPS. Masyaikh are determined on the basis of deliberation from the Sidogiri Family Council. The Family Assembly is a body whose members consist of grandson KH. Nawawie bin Noerhasan bin Noerkhotim. The Family Assembly is a body that serves to assist the tasks of the masyaikh in maintaining and establishing the foundation of PPS.

Management is a body that is appointed and determined by the PPS Family Assembly for a certain term as officers. The management functions as the executing body of the Sidogiri programs. The management are called the Sidogiri Daily Management. They consist of general chairman, deputy general chairman, general secretary, general treasurer chairman I, chairman II, chairman III and chairman IV. The administrator management under the daily management is always accompanied by the position name. So the structural position of the management in Sidogiri consists of: daily administrators, the executive board also includes supplementary management, assistant administrators, and special staff

The general chairman is chaired by the Daily Executive Board of Sidogiri. The secretariat is coordinated by the general secretary of Sidogiri, assisted by six secretaries (public relations and information, data and personnel, hardware and networking, correspondence and 
filing, graphic design, administration, multimedia documentation, systems development and information technology) with several staff management and officers. The Secretariat is the management center and the administrative process and all PPS services. ${ }^{60}$

The general treasurery coordinates: treasury section (expenditure and expenditure fields, revenue and income fields, inventory and asset management fields), kopontren and publishers. Treasury function records all sidogiri financial incomes and expenditures, standardizes pesantren financial reports by compiling reports in a valid and transparent manner, supervising all treasury activities of sidogiri. ${ }^{61}$

Chairperson I who coordinates ten units, each unit namely Tarbiyah wa Taklim Madrasah Agency, Laboratory of Madrasah Questions, Madrasah Miftahul Ulum (MMU) Idadiyah, MMU Ibtidaiyah, MMU Tsanawiyah, MMU Aliyah, Head of MMU 08 Surabaya, MMU Darul Khidmah Sidogiri Bekasi, TPQ (Al-Qur'an Educational Park) Sidogiri Surabaya and TPQ Sidogiri Bekasi. Chairperson II is responsible for santri residential areas which command 18 regional heads / sections starting from order and security, boarding areas A to Z, and heads of LPBAA. Chairman III supervises five chief coordinators: the head of the Ubudiyah division, head of the Kuliyah, head of the Taklimiyah wa Tahfizhul Qur'an, head of the Qurani Method Sidogiri and head of the library. Chairperson IV coordinated three heads, namely the head of the Sidogiri medical center, the head of the environmental hygiene department, the division of procurement, repair and maintenance of facilities. In addition to the management of Sidogiri as mentioned in the previous section, there are also institutions where in special coordination, namely the Amil Zakat Institution (LAZ) Sidogiri, Sidogiri Media, Santri Alumni Association of Sidogiri (IASS) and Harakah Alumni Santri Sidogiri (HMASS).

To simplify how network expansion is applied in Sidogiri, as an example of IASS. IASS is the official alumni organization of PPS.

60 Tamassya Sidogiri, Satu Mimpi Satu barisan (PP Sidogiri: Laporan Tahunan Pengurus PP Sidogiri, 2017), 50.

${ }^{61}$ Ibid., 50. 
This organization functions as a meeting place for each alumni; as a place to establish togetherness between them; and as a infrastructure of articulating the interests of PPS in the wider community. ${ }^{62}$ The Santri Alumni Association Organization of Sidogiri (IASS) is an organization under the vice chairman who specializes in handling alumni. IASS is divided into central management, regional administrators, sub-district administrators, and village coordinators. ${ }^{63}$ The management structure of IASS is divided into central management and regional administrators (PW). PW IASS currently has 24. Most in East Java, plus Jakarta, Bali, West Kalimantan, Central Kalimantan, East Kalimantan and Malaysia. IASS aims to empower alumni, as well as to encourage their action in the community. The management structure of IASS starts from the general chairman, assisted by the secretariat general and is assisted by the chairman of I-IV. IASS management namely (1) planning which includes data collection on alumni and program planning; (2) organizing; (3) alumni development; (4) empowerment of alumni; (5) evaluation

There are four fields handled by IASS. First, dakwah (the missionary) and social fields: trying to build the values of religiosity by applying it to everyday life. The emphasis model is in the form of recitation, and meeting at the regional or sub-district management level in the form of halaqah. Second, education and training: trying to improve the quality of human resources in order to be good moral character, skilled, professional, and creative. Right now IASS is still incessant in the field of education and training. Now there are associations of Sidogiri alumni entrepreneurs, the Dai Sidogiri association and so on. This means that for successful alumni, it is expected to provide or share to other alumni by giving a training. Third, the field of sharia and positive law: trying to provide a correct understanding and answer to the religious issues of the Ummah, as

\footnotetext{
62 Tamassya Sidogiri, Satu Mimpi Satu barisan, 174.

${ }^{63}$ Ainur Rifqi, Ali Imron, \& Murtiningsih, "Manajemen Alumni Di Pondok Pesantren Modern Dan Salaf (Studi Di Pondok Pesantren Nurul Jadid Dan Pondok Pesantren Sidogiri)," Jurnal Pendidikan: Teori, Penelitian, dan Pengembangan 1, no. 4 (2016): 688.
} 
well as providing advocacy, especially for alumni of PPS. Finally, Economics and Business: trying to develop a balanced economic life, especially among alumni of PPS and society. The alumni generally graduated from Aliyah. Even though they did not attend formal school but they were able to carry out professionally the economic activities belonging to the Pesantren and the business of the Sidogiri alumni. If there is a need that requires knowledge, Pesantren will send it to university.

IASS collaborates with business institutions of PPS and other business institutions managed by alumni to empower alumni by prioritizing alumni in submitting work applications. ${ }^{64}$ Business institutions owned include the cooperative boarding school of Sidogiri (Kopontren Sidogiri), Amil Zakat Institution (LAZ) Sidogiri, BMT Maslahah, BMT UGT. The requirements for applying at BMT for alumni are made easier than those who are non-alumni. Empowerment in the form of contributions to Pesantren is also done through alumni by donating money and expertise to develop pesantren.

Therefore, it is expected that IASS: (1) Alumni who have the ability in the field of law, da'wah, education and business economics can be accommodated so that the objectives of implementing Islamic law in everyday life can be achieved (2) Long-term goals in order to have a positive impact on society while the short-term scientific activities such as halaqah are related to the four fields above (3) creating as much entrepreneurship as possible. if they are printed as entrepreneurs, it will be easy to create jobs. This means that we develop alumni into entrepreneurs, if they become entrepreneurs, it is easy to create jobs for the community

\section{Institutionalizing of Khidmah Lil Ma'had Dan Khidmah Lil Ummat}

Al-quran and As-Sunnah encourage us to compete in doing good deeds for the achievement of hereafter. Islam is a religion that is very concerned with work or charity, Islam does not want to even hate people who are lazy. ${ }^{65}$ At the beginning of PPS establishment the aim

\footnotetext{
${ }^{64}$ Ibid., 688-689.

${ }^{65}$ J Hamidi \& M Luthfi, Entrepreneurship Kaum Sarungan (Jakarta: Khalifa, 2010).
} 
of the Pesantren education system was based on lillah billah and the intention of sincere da'wah to uphold the sentences of Allah swt ( $i z z u l$ Islam wal muslim). Developing to instill tafaqquh fiddin ethos among santri, in order that they are able to understand Islamic teachings in a good and correct manner, have a noble character, which has implications for their family and society, as well as nation and state. ${ }^{66}$ The development and improvement of education is always sought continuesly by PPS. The prioritized concept is an improvement in all time. ${ }^{67}$

PPS wants more benefit for the community, not just Islamic education which has been the focus of the salaf pesantren in Indonesia. The usefulness of the "peculiarities" that were developed by PPS, namely Islamic preaching, Islamic education, and also the economic development of the people. These factor encouraged PPS to develop special education programs at the level of aliyah into three major, namely da'wah, muamalah, and tarbiyah. By spreading Islam through the transfer of knowledge to the santri in accordance with the interests of the santri in three respects above. It is expected that santri after taking education in Pesantren Sidogiri can take part in their respective interests in the community. ${ }^{68}$

Concern about the lack of religious education in the community, PPS established a branch madrasah affiliated with MMU Sidogiri. The presence of branch Madrasah in remote areas is very helpful for the community to get proper religious education. The opening of this branch of the madrasah have been followed by the sending of santri as assignment teachers to those areas since 1961. Santri is assigned to madrassah or others pesantren which spread throughout Indonesia, even in areas minus Islam. ${ }^{69}$

\footnotetext{
${ }^{66}$ Faiqoh, Orientasi Pendidikan Pesantren Sidogiri, 342.

67 Abd Hadi Rohmani, Transformasi Sistem Pembelajaran Di Pondok Pesantren Sidogiri, 571.

68 Indah Piliyanti, "Pendidikan Ekonomi Islam Di Indonesia: Pengalaman Pesantren Sidogiri Pasuruan Jawa Timur," Jurnal Hukum Islam (JHI) 10, no. 2 (2012): 233.

69 Sidogiri, "280 tahun perjalanan Pondok Pesantren Sidogiri," 2017. https://www.youtube.com/watch?v=2NmvfTFeTAg.
} 
Beginning in 1997, Pasuruan was so calm. However, a pinch of anxiety overlapped the teachers of PPS. In the midst of the piece of religious life in the East Java province, Java Island is hidden by an acute "virus" riba (usury). ${ }^{70}$ The condition of the people who are entangled with poverty, moneylenders and usury, and banks cannot handle them because they are considered un-bank-able so that PPS comes to overcome this problem by introducing BMT. Currently there are BMT Maslahah, BMT UGT Sidogiri, and sharia BPR and the development is very good.

As an example, the total assets of Sidogiri BMT UGT in 2017, financial year reached $\mathrm{Rp} 2.4$ trillion. $^{71}$ The number of branches reaches 300 more that spread over ten provinces. One branch is even located in Malaysia. Zakat payments in 2016 reached Rp 8.5 billion and the number of cooperative members reached 16,647 people.

BMTs have positive impact on the members' physical wellbeing, social well-being and quality of life which measured by Satisfaction with Life. As Islamic microfinance institutions, BMT has effectively played its role in enhancing the participants' socioeconomics status by providing financing access and social development programs to the poor and the low income households. Consequently, this contribute to the improvement of the participants' physical and social well-being as well as quality of life. ${ }^{72}$

When the pesantren graduates are impossible to be accommodated as religious teachers and preacher or matters related to religion, PPS answered them by creating value-based entrepreneurship students. The value developed by PPS in supporting its Entrepreneurship Learning quality management application, which includes a number of value components, among others: (a)

\footnotetext{
${ }^{70} \mathrm{M}$ Syaiful Bakhri, Kebangkitan Ekonomi Syariah di Pesantren-Belajar dari Pengalaman Sidogiri (Pasuruan: Cipta Pustaka Utama, 2004), 117.

71 Gatra, "Konglomerat Bersarung Sidogiri," 2018 https://www.gatra.com/rubrik/ ekonomi/328110-Konglomerat-Bersarung-Sidogiri.

${ }^{72}$ Muhammad Quraisy, Syed Othman Alhabshi \& Shaikh Hamzah Abdul Razak, "The Impact Of Islamic Microfinance In Enhancing The Well-Being And Quality Of Life: Case Study Of Islamic Financial Cooperative (BMT) In Indonesia," South East Asia Journal of Contemporary Business, Economics and Law 13, no. 3 (2017): 10.
} 
Professionalism value which includes; high commitment, discipline, responsibility, and standardization of performance; (b) Scientific values include: science based on the field of science development, and the field of skills development; and (c) The locality values of pesantren include: ketawadlu'an (humble), kenubuwahan values (siddiq, amanah, tabligh, and fathanah), concern for the values of the ummah's welfare, and prioritizing halal principles. ${ }^{73}$

Islam has set a guideline in order to become successful as a businessman through fortifying their individual ethics. ${ }^{74}$ In Islam, becoming an entrepreneur is not only all about reaping profit, but also satisfying customers' needs. Entrepreneurs who wanted to become successful, has to follow our prophet's style of doing business. Islam lays immense stress on morals and virtues and warns forcibly against vice; it demands the utmost level of commitment to commandments in this respect and promises the greatest rewards for those who observe them and the utmost penalty for those who do not, in this existence and hereafter.

According Gümüsay, entrepreneurship from an Islamic Perspective (EIP) is more than a simple summation of Islam and entrepreneurship. ${ }^{75}$ It is based on three interwoven pillars. The first pillar, based on the definition of entrepreneurship, is the pursuit of opportunities. The second pillar is socioeconomic or ethical. Effectively, EIP is guided by a set of norms, values and recommendations. The third pillar is religio-spiritual and links people to God with the ultimate objective of pleasing Allah.

\section{Discussions}

\section{Productive Culture Adheres to Social Capital}

\footnotetext{
73 Piliyanti, Pendidikan Ekonomi Islam Di Indonesia: Pengalaman Pesantren Sidogiri Pasuruan Jawa Timur, 233.

${ }^{74}$ Mohammad Noorizzuddin Nooh, Entrepreneurship, Ethics and Religiosity, 175.

75 Abdulloh Kasor, Eri Pratikto, Agung Winarno, Spiritual Entrepreneurship Education in Islamic Boarding School: A Case Study at Pondok Pesantren Sidogiri Pasuruan, Each Jawa, Indonesia. 397.
} 
A culture of productivity consists of the shared understandings of workers in highly productive settings and the commonly known procedures and rules these workers use to understand productivity and be productive. The culture does not cause productivity; rather, the culture is the insider's view of the fundamental structures and processes that constitute productivity in a particular setting. ${ }^{76} \mathrm{~A}$ culture of productivity defined in terms of the foregoing core values and norms of productivity. The foregoing considerations lead to following three basic prerequisites for a continual striving toward higher productive achievements; (1)high level of work competence, pride in excellence and willingness to learn and excel in work performance of organization personnel at all levels (2) a high innate sense of duty and responsibility in carrying out their tasks and activities in and for the well-being of the organization (3) a high orientation of non-egoistic, sincere and willing interpersonal cooperation in work performance based on mutual trust, respect and shared identification with the organization. ${ }^{77}$

In Islam, a Muslim is encouraged to do something with the best performance, not only for himself but also for others. It is a measure of towering personality. Islam encourages people to produce and play a role in various forms of economic activity. Islam bless the work of this world and make it part of worship and jihad. By working, people can meet their needs, provide for his family and make a good thing to their neighbors. ${ }^{78}$ The productivity culture produces a series of values in their behavior that productivity is good, transparency and accountability are good, the existence of regulatory standards is good, investment in capability and technology is needed, honesty and trust are mandatory, alumni and santri are assets, and education, training and skills are important to support more productive work

\footnotetext{
76 Gib Akin and David Hopelain, "Finding the culture of productivity," Organizational Dynamics 14, no. 3 (1986): 20.

77 P. N. Rastogi, "The Culture of Productivity Source" Indian Journal of Industrial Relations 22 no. 2 (1986): 150-151.

${ }^{78}$ Khoirul Fathoni dan Mohammad Ghozali, “Analisis Konsep Produktivitas Kerja Konvensional Dalam Pandangan Islam,” Al Tijarah 3, no. 1 (2017): 1.
} 
Social Capital Stock Increases rapidly Because It Combines Two Aspects: Cling to Ahlusunnah Wal Jama'at and Welcome and Respond to the Advancement of Science and Technology

Kyai offers an agenda of change that he deems appropriate to the needs of the community he leads. He is not less participated because of delaying the coming of change through the process of filtering information, but he is fully instrumental because he understands that social change is an inevitable development. The problem he faced was how the need for change could be fulfilled without destroying existing social ties, but rather by using them as the desired mechanism of social change. ${ }^{79}$

Santri is familiar with technologist, santri is a writer, santri is a programmer, santri become successful entrepreneurs, santri are Arabic and English speakers, santri become managers, santri become kyai, lecturers, religious teachers and many more. There is no limitation in a career as long as it is true for the ummah. The orientation of Sidogiri is to create santri who are worshipers who fly as high as possible to reach dreams, answer and help the problems of the ummah

PPS is included in the category of transformative Pesantren, still maintain the existing Pesantren tradition, on the other hand also receive and respond to innovative developments in new science and technology. ${ }^{80}$ PPS can uphold a culture that has become a characteristic for a long time. Traditionalism does not mean lagging behind, progress does not mean losing character, progress does not mean going with the flow. PPS stands among its traditionalism but is not eliminated by the flow of globalization and commercialization of education. ${ }^{81}$

\footnotetext{
${ }^{79}$ Hiroko Horikoshi, Kyai dan Perubahan Sosial, Thesis for the degree of Doctor of Philosohy in Antropology, University Illinois, USA. Umar Basalim dan Andi Muarly Sunrawa (Penerjemah). (Jakarta: Perhimpunan Pengembangan Pesantren dan Masyarakat (P3M) 1978): xviii.

80 Muhammad Arif, Pondok Pesantren dan Perubahan Sosial (Surabaya: IAIN Surabaya Disertasi, 2012), 102.

81 Siti Halimah, "Analisis Pendidikan Pondok Pesantren Sidogiri Pasuruan," AlMakrifat: Jurnal Kajian Islam, Kopertais (2017): 184.
} 
PPS is open to every form of change, and tries to take its lessons. Because every era has its own dynamics. In the learning system PPS, made improvements in various aspects, including also by applying the major system at the level of the Islamic Senior High School (MMU aliyah). The major that was developed almost matched the form in Islamic universities. Likewise, the composition of the curriculum presented, there are a number of general subjects that feel unfamiliar if discussed in the context of learning in the salaf pesantren (old school). These subjects, for example; theories of macro and micro economics, sociology, educational psychology, da'wah psychology, journalism, statistics, and several others. The learning transformation in PPS by using different major in $M M U$ aliyah is the answer to the anxiety of the modern society that requires integration between science and technology and the faith. ${ }^{82}$ PPS has done a comparative study program to learn from other institution which have better in the system. So that it can be applied later.

PPS implements Education approach of cultural, religious and economic. Cultural approach, pesantren look more at what is needed by the community, then pesantren tend to complement and protect. So, pesantren do not force people to do this or that, not compaling the community to follow this or that, but instead directed society through their culture. Second, religious approach, namely religious approach through education and social by adhering to salaf values. Third, economical approach, namely entrepreneurial spirit through Bayt alMâl wa al-Tamwîl (BMT), Cooperative Islamic Boarding School (Kopontren), Water Bottled Drinking (bottled water) "santri and Giriway", PT Hasbi, PT Pustaka, Agro Cooperative, and Rural Bank Sharî'ah (BPRS) ${ }^{83}$

\footnotetext{
82 Abd Hadi Rohmani, "Transformasi Sistem Pembelajaran Di Pondok Pesantren Sidogiri," Fikrotuna: Jurnal Pendidikan dan Manajemen Islam 6, no. 2 (2017): 583 584.

83 Chusnul Chotimah, Strategi Public Relations Pesantren Sidogiri Dalam Membangun Citra Lembaga Pendidikan Islam, 197.
} 


\section{Conclusion}

Local wisdom such as Hinduism, Buddhism and other religious beliefs are appreciated by the spreaders of Islam (walisanga) and then integrated into the doctrine and culture of Islam namely the teachings of ahlus sunnah waljamaah (sunni) with some basic principles such as tasamuh, tawazun, ta'adul (i 'tidal), tawasuth and tasyawur according to the basis of the Qur'an. The treasures about Islam in Indonesia cannot be separated from Islamic boarding schools (pesantren). The contribution to the development of social and cultural life of the community, especially through the preservation of local culture.

The scope of social capital includes social interaction ties of PPS (structural dimension), norm reciprocity (relational dimension) and shared vision (cognitive dimension) that are internalized in the environment of the Sidogiri family. Structural dimensions such as social interaction ties (network) of PPS consist of routine recitations, alumni ties, and togetherness in the style of pondok pesantren, istighozah, haul and akhir sanah and cooperation with other institutions outside pesantren. Norms consists of love and obedience to Masyaikh also their family, santri Sidogiri is one brother, discipline, barokah, and independence in the economy, as well as honest \& trustworthy behavior. Shared vision such as the development of science and institutions for the affirmation of ahlus Sunnah wa jamaah, khidmah lil ma'had khidmah lil ummah, ibadillah sholihin, simplicity, and creating entrepreneurship.

The transformation of social capital in PPS namely the expansion of the pesantren network through the development of the organizational structure establishment of new institutions, and institutionalize of khidmah lil ma'had and khidmah lil ummah. The social capital has a big impact, not only to create santri who have a strong religious knowledge and entrepreneurial spirit but also as a major trigger in the success of Pondok Pesantren Sidogiri in developing its economic business. The productive culture attached to social capital, moreover the increasing stock of social capital intend to combines two aspects namely clinging ahlusunnah wal jamaah and responding to advancement of science and technology. 


\section{Bibliography}

Abdusshomad, Muhyiddin. Fiqh Tradisionalis Jawaban Berbagai Persoalan Keagamaan Sehari-Hari. Malang: Pustaka Bayan bekerjasama dengan PP Nurul Islam, 2004.

Ahmad, Salis Ulinuha. "Pesantren Sebagai Modal Sosial dalam Strategi Pembangunan Desa di Jawa Timur." Akademika 7, No. 1 (2013).

Akin, Gib., and David Hopelain. "Finding the culture of productivity." Organizational Dynamics 14, no. 3 (1986):19-32.

Arif, Muhammad. Pondok Pesantren dan Perubahan Sosial, Surabaya: IAIN Surabaya Disertasi, 2012.

Arsyad, M. AT. "Kajian Kritis tentang Akulturasi Islam dan Budaya Lokal." Lentera Pendidikan 15, no. 2 (2012): 211-220.

Asnawan. "Islam dan Akulturasi budaya lokal di Indonesia." Jurnal Falasifa 2, no. 2 (2011).

Bakhri, Syaiful. M. Kebangkitan Ekonomi Syariah di PesantrenBelajar dari Pengalaman Sidogiri. Pasuruan: Cipta Pustaka Utama, 2004.

Batartama Pondok Pesantren Sidogiri (PPS). Trilogi Ahlusunah: Akidah, Syariah dan Tasawuf. Pasuruan: Sidogiri Penerbit, 2012.

Billah, M.M. "Pikiran Awal Pengembangan Pesantren." Pergulatan Dunia Pesantren Membangun dari Bawah, edited by $\mathrm{M}$. Dawam Rahardjo, 289-298. Jakarta: Cetakan Pertama, Perhimpunan Pengembangan Pesantren dan Masyarakat (P3M), 1985.

Bolino, M.C., W.H. Turnley, J.M. Bloodgood. "Citizenship behavior and the creation of social capital in organizations." Acad Manage Rev. 27 (2002): 505-522.

Bruinessen, Martin van. Kitab Kuning, Pesantren dan Tarikat; Tradisi-Tradisi Islam di Indonesia, Bandung, 1995.

C.M. Chiu, M.H. Hsu, E.T.G. Wang. "Understanding knowledge sharing in virtual communities: An integration of social capital 
and social cognitive theories." Decis Support Syst. 42 (2006) 1872-1888.

Chang, H.H., C. Y. Hung, C.Y. Huang., K.H. Wong and Y. Tsai. "Social capital and transaction cost on co-creating IT value towards inter-organizational EMR exchange." International Journal of Medical Informatics. www.elsevier.com/locate/worlddev.

Chaplin, Dell. "Social Capital and the Privatization of Public Goods." International Journal of Social Economics, MCB University Press 26 No.10/11 (1999):1302-1314.

Chiu. C.M., M.H. Hsu, E.T.G. Wang. "Understanding knowledge sharing in virtual communities: An Integration of Social Capital and Social Cognitive Theories." Decis Support Syst. 42 (2006): 1872-1888.

Chotimah, Chusnul. "Pendidikan Kewirausahaan di Pondok Pesantren Sidogiri Pasuruan." Inferensi, Jurnal Penelitian Sosial Keagamaan 8, no. 1 (2014): 115-136.

Chotimah, Chusnul. "Strategi Public Relations Pesantren Sidogiri dalam Membangun Citra Lembaga Pendidikan Islam." Islamica 7, no. 1, (2012).

Demirel, Serdar and Hikmatullah Babu Sahib. "Concept of Barakah in Qur'ān and Sunnah: Towards its Realization in Modern Discourse". FSM İlmî Araştırmalar Insan ve Toplum Bilimleri Dergisi, 5 (2015) Bahar. Sayı/Number 5 Y11/Year 2015 Bahar/Spring.

Dhofier, Zamakhsyari. Tradisi Pesantren: Studi tentang Pandangan Hidup Kyai. Jakarta: Lembaga Penelitian, Pendidikan dan Penerangan Ekonomi dan Sosial (LP3ES), 1983.

Dzikra Majalah Ijtihad. Jejak langkah 9 Masyaikh Sidogiri 1. Edisi Keempat. Pasuruan: Pustaka Sidogiri PP Sidogiri, 2013a.

Dzikra Majalah Ijtihad. Jejak langkah 9 Masyaikh Sidogiri 2. Edisi Keempat. Pasuruan: Pustaka Sidogiri PP Sidogiri 2013b.

Faiqoh. "Orientasi Pendidikan Pesantren Sidogiri." Edukasi 10, no 3 (2012): 329-347. 
Farchan, Hamdan., dan Syarifudin. Titik Tengkar Pesantren: Resolusi Konflik Masyarakat Pesantren. Yogyakarta: Pilar Religia, Kelompok Pilar Media, 2005.

Fathoni, Khoirul dan Mohammad Ghozali. "Analisis Konsep Produktivitas Kerja Konvensional dalam Pandangan Islam”. Al Tijarah 3, no. 1 (2017): 1-14.

Fatoni, Muhammad Sulton. Strategi organisasi Pondok Pesantren Sidogiri dalam Mewujudkan Civil Society: Analisa Kapital Social. UI: Tesis, 2006.

Furubotn, Eirik, G., and Rudolf Richter. Institutions and Economic Theory: the Contribution of the New Institutional Economics. Ann Arbor, the University of Michigan Press 2000.

Gatra. "Konglomerat Bersarung Sidogiri." 2018 https://www.gatra. com/rubrik/ekonomi/328110-Konglomerat-Bersarung-Sidogiri.

Gümüsay, A. A. "Entrepreneurship from an Islamic perspective." Journal of Business Ethics 130, no. 1, (2015): 199-208 (402).

H.H Chang.H.H., S.S. Chuang. "Social capital and individual motivations on knowledge sharing: Participant involvement as a moderator." Inform Manag 48 (2011): 9-18.

Halimah, Siti. "Analisis Pendidikan Pondok Pesantren Sidogiri Pasuruan." Al-Makrifat: Jurnal Kajian Islam, Kopertais (2017).

Hamidi, J., \& Luthfi, M. Entrepreneurship Kaum Sarungan. Jakarta: Khalifa, 2010.

Hasbullah, Moeflich. Islam dan Transformasi Masyarakat Nusantara kajian sosiologi sejarah Indonesia. Jakarta: Kencana, 2017.

Horikoshi, Hiroko. Kyai dan Perubahan Sosial. Thesis for the degree of Doctor of Philosohy in Antropology, University Illinois, USA. Umar Basalim dan Andi Muarly Sunrawa (Penerjemah). Jakarta: Perhimpunan Pengembangan Pesantren dan Masyarakat (P3M) 1978.

Isham, Jonathan., Thomas Kelly., and Sunder Ramaswamy. "Social Capital and Well-being in Developing Countries: an Introduction." Social Capital and Economic Development: 
Well-being in Developing Countries, edited by Edward Elgar, 1-226. USA: Cheltenham, UK. Northampton, 2002.

Johnson, Bjorn., and Klaus Nielsen. 1998. "Introduction and Economic Change." Institutions and Economic Change: New Perspectives on Market, Firm, and Technology, edited by Klaus Nielsen and Bjorn Johnson, xiii-xxvii. Cheltenham UK: European Association for Evolutionary Political Economy, Edward Elgar, 1998.

Kutsiyah, Farahdilla. 2008. Analisis Modal Sosial dan Biaya Transaksi

Pengembangan Agribisnis di Pesantren (kasus: program bantuan pinjaman langsung masyarakat pada dua pesantren di Kabupaten Pamekasan), Malang: Disertasi Universitas Brawijaya, 2008.

Kutsiyah, Farahdilla. "Analisis Kinerja Program bantuan Pinjaman langsung Masyarakat Melalui Lembaga pesantren di Madura." Jurnal Agro Ekonomi (JAE), Pusat Analisis Sosial Ekonomi Dan Kebijakan Pertanian, Puslitbang Bogor (2009).

Lu.Y, D.Yang. "Information Exchange In Virtual Communities Under Extreme Disaster condition." Desic Support Syst. 50 (2011): 529-538.

M.C. Bolino, W.H. Turnley, J.M. Bloodgood. "Citizenship behavior and the Creation of Social Capital in Organizations." Acad Manage Rev. 27 (2002): 505-522.

Ma'ruf. M. "Eksistensi Pondok Pesantren Sidogiri Pasuruan dalam Mempertahankan Nilai-Nilai Salaf di Era Globalisasi." Evaluasi. 1, no. 2, (2017).

Madjid, Nurcholish. Merumuskan Kembali Tujuan Pendidikan Pesantren. Pergulatan Dunia Pesantren Membangun dari Bawah. Jakarta: Cetakan Pertama, Perhimpunan Pengembangan Pesantren dan Masyarakat (P3M), 1985.

Madjid, Nurcholish. Bilik-Bilik Pesantren. Jakarta: Paramadina, 1997. Masyitha, Dewi \& Alvan Fathony. "Studi Analisis Peran Pesantren Sidogiri Dalam Pembentukan Karakter Kemandirian Ekonomi Masyarakat Perspektif Sosiologi." Profit 01 no 01, (2017). 
Milgrom, Paul., and John Robert. Economics, Organization and Management. New Jersey: Prentice Hall, Engelewood Cliffs, 1992.

Minten, Bart., and Marcel Fafchamps. 1999. Social Capital and The Firm: Evidence from Agricultural Trade. Working Paper 21, the World Bank, Social Capital Initiatives, Washington, DC (1999).

Mochtar, M. Masyhuri. Dinamika kajian Kitab kuning di Pesantren. Pasuruan: Pustaka Sidogiri. PP Sidogiri, 2016.

Nahapiet.J, S. Ghostal. "Social Capital, Intelectural Capital, and the Organizational Advantage." Acad manage Rev. 23. (1998) 242266.

Nooh, Mohammad Noorizzuddin. "Entrepreneurship, Ethics and Religiosity". Journal of Business \& Economic Policy 2, no. 4 (2015).

North, Douglas, C. "Institutions, Transaction Cost and Economic Growth" Economic Inquiry 25 (1987).

North, Douglas, C. "Revolution in Economics." Institutions, Contracts, and Organizations. Perspective from New Institutional Economics, edited by Claude Menard, 37-41. Cheltenham UK: Edward Elgar, 2006.

NU. Kopontren Sidogiri, Sukses dengan Meneladani Sifat Rasul. 2007. http://www.nu.or.id/post/read/9812/kopontren-sidogiri-suksesdengan-meneladani-sifat-rasul.

PDPP. Statistik Pendidikan Diniyah dan Pesantren - Pendis Kemenag. 2016. pendis.kemenag.go.id/file/dokumen/bukusaku1102.pdf.

Permani, R. The economic of Islamic Education: Evidence from Indonesia. University of Adelaide, Thesis 2009.

Piliyanti, Indah. "Pendidikan Ekonomi Islam di Indonesia: Pengalaman Pesantren Sidogiri Pasuruan Jawa Timur." Jurnal Hukum Islam (JHI) 10, no. 2 (2012): 221-240

Puspitasari, Ratna. "Studi Komparasi Model Pengembangan Kecakapan Hidup (Life Skill) Santri di Pondok Pesantren AnNashr (Tarbiyatul Banin) Cirebon Dengan Santri di Pondok 
Pesantren Sidogiri Pasuruan.” Holistik 14, no. 02 (2013/1435 $\mathrm{H})$.

PWNU, Jawa Timur. Aswaja An-Nahdliyah. Ajaran Ahlussunnah wa Al-jamaah yang Berlaku di Lingkungan Nahdlatul Ulama. Khalista Surabaya dan LTN NU Jawa Timur, 2007.

Quraisy, Muhammad., Syed Othman Alhabshi \& Shaikh Hamzah Abdul Razak. "The Impact of Islamic Microfinance in Enhancing the Well-Being and Quality of Life: Case Study of Islamic Financial Cooperative (BMT) In Indonesia." South East Asia Journal of Contemporary Business, Economics and Law 13, no. 3 (2017):2289-1560.

Rahardjo, Dawam, M. "Dunia Pesantren dalam Peta Pembaharuan." Pesantren dan Pembaharuan, edited by M. Dawam Raharjo, 138. Jakarta: Cetakan Keempat, Lembaga Penelitian, Pendidikan dan Penerangan Ekonomi dan Sosial, 1988.

Rastogi. P. N. "The Culture of Productivity Source." Indian Journal of Industrial Relations 22 no. 2 (1986): 148-167.

Reginald, Azel Raoul dan Imron Mawardi, "Kewirausahaan Sosial Pada Pondok Pesantren Sidogiri Pasuruan." JESTT 1, no. 5 (2014): 333-345.

Rifqi, Ainur, Ali Imron, \& Murtiningsih. 2016. "Manajemen Alumni di Pondok Pesantren Modern dan Salaf (Studi di Pondok Pesantren Nurul Jadid dan Pondok Pesantren Sidogiri)." Jurnal Pendidikan: Teori, Penelitian, dan Pengembangan 1, no. 4 (2016): 686-691.

Rohmani, Abd Hadi. "Transformasi Sistem Pembelajaran di Pondok Pesantren Sidogiri." Fikrotuna: Jurnal Pendidikan dan Manajemen Islam 6, no. 2 (2017): 566-586

Sen, Amartya. Development as Freedom. Inc. New York: Anchor Books, a division of Random House, 1999.

Sidogiri. 280 Tahun Perjalanan Pondok Pesantren Sidogiri, 2017. https://www.youtube.com/watch? $v=2 N m v f T F e T A g$.

Sopidi. "Integrasi Modal Sosial dan Budaya dalam Pengembangan Nilai-Nilai Pendidikan Karakter di Pondok Pesantren Modern 
As-Sakinah Sliyeg Indramayu." Holistik 15, no. 02, (2014): 287-08.

Spradley, James P. Metode etnografi. Penerjemah M.Z. Elizabeth. Yogya: PT Tiara Wacana, 1997.

Streeten, Paul. "Reflection on Social and Antisocial Capital". Social Capital and Economic Development: Well-being in Developing Countries. Edited by Jonathan Isham et al. Edward Elgar, 4057. USA: Cheltenham, UK. Northampton, 2002.

Syihab, Usman. "Peranan Agama dalam Restorasi Peradaban Umat Islam Menurut Muhammad Fethullah Gulen." Jurnal Tsaqafah 10, no. 2 (2014).

Tamassya Sidogiri. Satu Mimpi Satu barisan. PP Sidogiri: Laporan Tahunan Pengurus PP Sidogiri, 2017.

Turmudi, Endang. Perselingkuhan Kiai dan Kekuasaan. Supriyanto Abdi (Penerjemah) Yogyakarta: LKiS, 2004.

Wahid, Abdurrahman. "Pesantren sebagai Subkultur." Pesantren dan Pembaharuan, edited by M. Dawam Rahardjo, 39-60. Jakarta: Cetakan Keempat, Lembaga Penelitian, Pendidikan dan Penerangan Ekonomi dan Sosial, 1988.

Wahid, Abdurrahman. Pergulatan Negara, Agama dan Kebudayaan, Jakarta: Desantara, 2001.

Wallis, Joe., Paul Killerby., and Brian Dollery. Social Economics and Social Capital. International Journal of Social Economics 31, no. 3 (2004) Emerald Group Publishing Limited.

Woolcock, Michael. "Social Capital and Economic Development: Toward a Theoretical Synthesis and Policy Framework." Theory and Society. 27. Kluver Academic Publisher. Printed In The Netherlands. (1998).

Yeager, Timothy J. Institutions, Transition Economies and Economic Development. Westview Press, a Member of the Perseus Books Group, 1999.

Zuhri, Saifuddin. Guruku Orang-Orang Dari Pesantren. Yogyakarta: Pustaka Sastra LkiS, 2001. 